\title{
УAK 343.2/7
}

DOI: 10.35750/2713-0622-2021-2-314-325

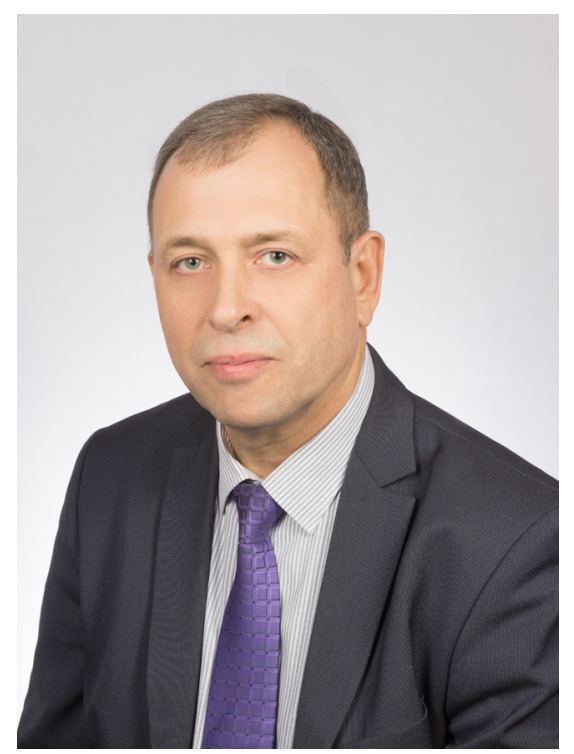

\section{Нечепуренко}

Алексей Алексеевич

Омская академия МВА России (Омск, Россия)

nechepurenko_oma@mail.ru ORCID: 0000-0001-8666-0509

\section{Киючевые слова}

уголовная ответственность, судимость, ограничение прав, освобождение от уголовной ответственности по нереабилитирующим основаниям, правовые позиции Конституционного Суда

\section{Пределы правоограничений, устанавливаемых Аля миц, совершивших преступления}

\section{Аннотация}

Анализируются подходы российского законодателя к установлению правоограничений для лиц, совершивших преступления. Показано, что данные правоограничения не исчерпываются теми, которые содержатся в мерах уголовной ответственности и являются ответной реакцией на совершение того или иного преступления. Проявив свою опасность для общества, преступник претерпевает и иные ограничения прав как в период судимости, так и за его пределами. Более того, многие правоограничения распространяются не только на лиц, которые являются или являлись судимыми, но и на освобожденных от уголовной ответственности по нереабилитирующим основаниям. Приводятся ключевые правовые позиции Конституционного Суда Российской Федерации по спорным вопросам введения законодателем тех или иных правоограничений для лиц, совершивших преступления, и обосновывается вывод, что в настоящее время многие запреты для таких лиц, касающиеся занятия трудовой деятельностью, сформулированы противоречиво. Для решения данной проблемы автором предлагаются как стратегические подходы к реформированию института судимости, так и тактические, касающиеся универсализации запретов для лиц, совершивших преступления. Реализация последних связана с внесением уточняющих формулировок во многие федеральные законы, устанавливающие запреты для таких лиц, но не требует их кардинальной переработки. В частности, речь идет об установлении равных запретов при поступлении на службу в правоохранительные органы и нахождении на этой службе, о единообразном указании в федеральных законах перечня видов освобождения от уголовной ответственности, являющихся основанием для запрета на службу в правоохранительных органах и др.

Для цитирования: Нечепуренко, А. А. (2021) Пределы правоограничений, устанавливаемых для лиц, совершивших преступления. Российский девиантологический журнал, 1(2), 314-325. DOI: 10.35750/2713-0622-2021-2-314-325. 
Alexey A. Nechepurenko

Omsk Academy of the MIA of Russia

(Omsk, Russia)

nechepurenko_oma@mail.ru

ORCID: 0000-0001-8666-0509

\section{Legal Restrictions for Persons Who Have Committed Crimes}

\section{Abstract}

The approaches of the Russian lawmaker to institute control over law for persons who have committed crimes are analyzed in the article. The paper investigates the fact that given legal restrictions are used as retaliatory measures not only for those who have committed crimes. Having manifested the danger for the society the criminal suffers from other restrictions of the rights during the court procedure and furthermore. Moreover, many legal restrictions are applied not only to the persons who are under trial or have a criminal record but also to those who are relieved of criminal responsibility due to nonrehabilitating circumstances. Key law positions of the Constitutional Court of the Russian Federation on arguable points of lawmaker's introduction of law restrictions for the people who have committed crimes are formulated. Conclusions are drawn that many legal restrictions for such category of people concerning their labour activities contradict each other. Recommendations of strategic and tactical character are given, such as to reform the institute of previous convictions and to make universal law restrictions for those who have committed crimes. The realization of the tactical aspect is connected with the procedure of giving more precise definitions to many federal laws dealing with legal restrictions for this category of people. In particular, the question is about complete equality of prohibitions when joining and serving in law enforcement agencies, about federal unique list of discharge from criminal responsibility which is the reason to prohibit service in law enforcement agencies and other agencies.

\section{Keywords}

criminal responsibility, conviction, legal restriction, relief of criminal responsibility due to non-rehabilitating circumstances, legal positions of the Constitutional Court

For citation: Nechepurenko, A. A. (2021). Legal Restrictions for Persons Who Have Committed Crimes. Russian Journal of Deviant Behavior, 1(2), 314-325. DOI: 10.35750/2713-0622-2021-2-314-325.

\section{Введение}

Крайним проявлением поведения, отклоняющегося от общепринятых в обществе норм, выступает совершение преступления. Посредством совершения преступления человек транслирует окружающим свое пренебрежение к наиболее значимым общественным ценностям, и в результате констатации в установленном порядке его авторства в данном преступлении государство приобретает право применять к нему меры уголовной ответственности и безопасности.

Возникает резонный вопрос: почему государство ущемляет права лица, совершившего преступление, не только в период срока судимости, но и за его пределами, а в большинстве случаев делает такие правоограничения пожизненными? Ответ на этот вопрос можно получить только на основе анализа механизма образо- вания общественной опасности. Ученые, занимавшиеся изучением данного сущностного свойства преступления, отмечают, что такой механизм, основанный на прецедентном поведении преступника, включает в качестве обязательного элемента общественной опасности личность преступника, «самозаявление» лица о своей опасности для общества путем совершения преступления. Так, А. И. Марцев, аргументируя тезис, что общественная опасность преступления в значительной мере определяется личностью правонарушителя (Марцев, 2012, с. 11), ссылался на доказанность данного положения в одном из фундаментальных трудов В. Д. Филимонова (Филимонов, 1970). В свою очередь Б. С. Никифоров на этот счет отмечал следующее: «Если от отвлеченных соображений на данную тему обратиться к повседневным наблюдениям, то они под- 
сказывают нам, что особое чувство (настороженности? тревоги? страха?), которые мы испытываем при общении с преступниками в местах лишения свободы или после отбытия ими наказания, на воле, проистекает от ощущения того, что своим прошлым поведением они заявили о своей опасности для общества. Определенные правоограничения, вызванные наличием судимости, в частности, при поступлении на работу, связанную с материальной ответственностью, имеют, на наш взгляд, не карательный, а “предохранительный” характер: лицо, совершившее, например, хищение, тем самым заявило о своей способности при случае совершить преступление еще раз, и мы стремимся не предоставлять ему такого “случая”. Опасения, которые мы испытываем, садясь в машину к человеку, “зарекомендовавшему” себя в прошлом совершением ряда аварий, имеет то же происхождение» (Никифоров, 1981, c. 68-69).

Здесь следует сделать поправку на то, что государство в ряде случаев теряет доверие к лицу, совершившему любое преступление или преступление определенной категории либо вида, не только на период судимости, но и на более продолжительный срок. Причем принципиального значения не имеет факт признания лица виновным только в установленном Конституцией Российской Федерации порядке, т. е. в обвинительном приговоре суда, вступившем в законную силу. Так, Конституционный Суд Российской Федерации неоднократно подтверждал, что хотя решение о прекращении уголовного преследования по нереабилитирующим основаниям не подменяет решения суда и не является актом, которым устанавливается виновность обвиняемого в том смысле, как это предусмотрено ст. 49 Конституции Российской Федерации, тем не менее, при соблюдении прав участников уголовного судопроизводства, что предполагает, в частности, необходимость получения согласия подозреваемого (обвиняемого) на прекращение уголовного дела, нет оснований считать права и законные интересы лица, освобождаемого от уголовной ответственности, нарушенными ${ }^{1}$. Иными словами, виновность такого лица в совершении преступления все же устанавливается, хотя и не в том порядке, который предусмотрен Конституцией РФ. В постановлении об освобождении от уголовной ответственности по нереабилитирующим основаниям лицо не признается виновным, а отмечается, что оно признает свою вину в совершении преступления. Главное здесь не форма, а содержание такого юридического факта. И при вынесении обвинительного приговора, и при постановлении об освобождении от уголовной ответственности по нереабилитирующим основаниям наступают в целом ряде случаев аналогичные последствия: лишение лица, совершившего преступления, права заниматься определенными видами деятельности. Безусловно, ограничивать права лиц, проявивших свою общественную опасность, необходимо, но нельзя игнорировать существование проблемы целесообразности установления определенных пределов для действия таких правоограничений.

\section{Основная часть}

Для того чтобы разобраться в вопросе о возможных пределах ограничений, налагаемых государством на лиц, совершивших пре-

ступления, нужно достаточно четко различать правоограничения, налагаемые в пределах срока судимости, и иные правоограничения, которые являются последствием констатации в законе того факта, что то или иное лицо когда-либо совершило преступление.

В пределах судимости лицо, по вступившему в законную силу приговору суда признанное виновным в совершении преступления, претерпевает назначенное наказание либо испытание, регламентированное ст. 73, 79, 82, $82^{1}$ УК РФ. Кроме того, в этих пределах наряду с предусмотренными в уголовном законе на преступника налагаются еще и иные правовые ограничения в случаях и в порядке, установленных федеральными законами, на что законодатель прямо указал, из-

По делу о проверке конституционности статьи 6 УПК РСФСР в связи с жалобой гражданина О. В. Сушкова: Постановление Конституционного Суда Российской Федерации от 28 октября 1996 г. № 18-П. См. также: По делу о проверке конституционности положений пункта 4 части первой статьи 24 и пункта 1 статьи 254 Уголовно-процессуального кодекса Российской Федерации в связи с жалобами граждан С. И. Александрина и Ю. Ф. Ващенко: Постановление Конституционного Суда Российской Федерации от 14 июля 2011 г. № 16-П. Здесь и далее, если не указано иное, доступ из справ.-правовой системы «КонсультантПлюс». 
менив в 2011 г. редакцию части 1 ст. 86 УК РФ². В то же время осталась без изменения часть 6 данной статьи, в которой говорилось, что погашение и снятие судимости аннулирует все правовые последствия, связанные с судимостью. На деле же сложилась совсем иная правовая ситуация: часть федеральных законов устанавливает правоограничения, связанные с контролем за поведением осужденных ${ }^{3}$ или с запретом занимать определенные должности либо заниматься той или иной деятельностью лицам в пределах срока их судимости ${ }^{4}$, а другая часть распространяет правоограничения как на судимых, так и на лиц, у которых судимость снята или погашена ${ }^{5}$. Кроме того, рядом федеральных законов установлены запреты на прием на службу и на нахождение на службе как для лиц, имеющих и имевших судимость, так и для лиц, освобожденных от уголовной ответственности по нереабилитирующим основаниям ${ }^{6}$. Понятно, что такое несоответствие декларативного предписания уголовного закона реальной правоприменительной ситуации не могло длительное время существовать, и законодатель счел необходимым кардинально изменить редакцию ч. 6 ст. 86 УК РФ, указав, что погашение или снятие судимости аннулирует только те правовые последствия, связанные с судимостью, которые предусмотрены в данном Кодексе ${ }^{7}$. Фактически, качнувшись этим предписанием в противоположную сторону, он опять исказил сложившуюся ситуацию с правоограничениями для лиц, совершивших преступления, поскольку, как показано выше, в ряде федеральных законов правоограничения для таких лиц действуют только в течение срока судимости. Было бы правильным продолжить данную формулировку ч. 6 ст. 86 УК РФ примерно такими словами: «...а также иные правовые последствия, если они предусмотрены федеральными законами только на период судимости».

О том, что в системе правоограничений для лиц, совершивших преступления, длительное время было и остается далеко не все идеально, заставляют задуматься три показательных в этом плане решения Конституционного Суда Российской Федерации, вынесенных в 2013 и 2014 гг. В первом постановлении констатируется неконституционность безусловного и бессрочного запрета для всех лиц, совершивших преступления, перечисленные в соответствующих статьях Трудового кодекса Российской Федерации (за исключением тяжких и особо тяжких преступлений, а также преступлений против половой неприкосновенности и половой свободы личности), заниматься педагогической деятельностью, а также деятельностью в сфере образования, воспитания и развития несовершеннолетних ${ }^{8}$. Федеральный законодатель во исполнение

2 О внесении изменений в отдельные законодательные акты Российской Федерации в связи с принятием Федерального закона «Об административном надзоре за лицами, освобожденными из мест лишения свободы»: Федеральный закон от 6 апреля 2011 г. № 66-Ф3.

3 Об административном надзоре за лицами, освобожденными из мест лишения свободы: Федеральный закон от 6 апреля 2011 г. № 64-Ф3 (за пределы судимости административный надзор может быть распространен только на осужденных, к которым применяется принудительное лечение от педофилии (п. 3 ч. 1 ст. 5)).

О государственной гражданской службе Российской Федерации: Федеральный закон от 27 июля 2004 г. № 79-Ф3 (ст. 16); О службе в таможенных органах: Федеральный закон от 21 февраля 1997 г. № 114-Ф3 (ст. 7); О ведомственной охране: Федеральный закон от 14 апреля 1999 г. № 77-Ф3 (ст. 7); О присяжных заседателях федеральных судов общей юрисдикции в Российской Федерации: Федеральный закон от 20 августа 2004 г. № 11-Ф3 (ст. 3); О частной детективной и охранной деятельности: Закон Российской Федерации от 11 марта 1992 г. № 2487-1 (ст. ст. 6, 111ㅜ); Об адвокатской деятельности и адвокатуре Российской Федерации: Федеральный закон от 31 мая 2002 г. № 63-Ф3 (ст. 9) и др.

5 Об оружии: Федеральный закон от 13 декабря 1996 г. № 150-Ф3 (ст. 13); О прокуратуре Российской Федерации: Федеральный закон от 17 ноября 1995 г. № 168-Ф3 (ст. 401); О выборах депутатов Государственной Думы Федерального Собрания Российской Федерации: Федеральный закон от 22 февраля 2014 г. № 20-Ф3 (ст. 4) и др.

6 О службе в органах внутренних дел Российской Федерации и внесении изменений в отдельные законодательные акты Российской Федерации: Федеральный закон от 30 ноября 2011 г. № 342-Ф3 (ст. ст. 14, 17, 82); О статусе судей в Российской Федерации: Закон Российской Федерации от 26 июня 1992 г. № 3132-1 (ст. 4); О службе в органах принудительного исполнения Российской Федерации и внесении изменений в отдельные законодательные акты Российской Федерации: Федеральный закон от 1 октября 2019 г. № 328-Ф3 (ст. ст. 14, 17); О службе в уголовно-исполнительной системе Российской Федерации и внесении изменений в Закон Российской Федерации «Об учреждениях и органах, исполняющих уголовные наказания в виде лишения свободы»: Федеральный закон от 19 июля 2018 г. № 197-Ф3 (ст. ст. 14, 17); О Следственном комитете Российской Федерации: Федеральный закон от 28 декабря 2010 г. № 403-Ф3 (ст. ст. 16, 30); О Федеральной службе безопасности: Федеральный закон от 3 апреля 1995 г. № 40-ФЗ (ст. 16) и др.

О внесении изменения в статью 86 Уголовного кодекса Российской Федерации: Федеральный закон от 29 июня 2015 г. № 194-Ф3.

8 По делу о проверке конституционности пункта 13 части первой статьи 83, абзаца третьего части второй статьи 331 и статьи $351^{1}$ Трудового кодекса Российской Федерации в связи с жалобами граждан В. К. Барабаш, А. Н. Бекасова и других и запросом Мурманской областной Думы: Постановление Конституционного Суда Российской Федерации от 18 июля 2013 г. № 19 -П. 
данного постановления внес изменения в Трудовой кодекс, в Федеральный закон «О государственной регистрации юридических лиц и индивидуальных предпринимателей» и ряд других законодательных актов, возложив на комиссию по делам несовершеннолетних и защите их прав, созданную высшим исполнительным органом государственной власти соответствующего субъекта Российской Федерации, индивидуально решать вопрос о допуске лиц, чья судимость за совершение преступления небольшой или средней тяжести снята или погашена, а также освобожденных от уголовной ответственности по нереабилитирующим основаниям, к работе с несовершеннолетними, если она придет к выводу, что эти лица не представляют опасности для жизни, здоровья и безопасности несовершеннолетних 9 .

Еще одно постановление касалось проверки конституционности бессрочного и недифференцированного ограничения пассивного избирательного права лиц, когда-либо осужденных к лишению свободы за совершение тяжких и (или) особо тяжких преступлений. Такое ограничение также было признано не соответствующим Конституции Российской Федерации ${ }^{10}$, на основании чего были внесены изменения в ряд федеральных законов. Согласно этим изменениям лица, осужденные к лишению свободы за совершение тяжких и особо тяжких преступлений, получили право избираться Президентом Российской Федерации, в представительные органы Российской Федерации, на должность высшего должностного лица субъекта Российской Федерации, если после погашения или снятия судимости прошло 10 и 15 лет соответственно ${ }^{11}$. Однако спустя шесть лет российский законодатель проявил непоследовательность в плане смягчения условий по восстановлению для лиц, совершивших преступления, конституционного права быть избранными и по своей инициативе ужесточил ограничение пассивного избирательного права для лиц, осужденных к лишению свободы за совершение указанных в соответствующем законе преступлений средней тяжести. В настоящее время это право такие лица получают не по истечении срока судимости, а спустя пять лет после ее погашения или снятия ${ }^{12}$.

Наконец, в 2014 г. Конституционный Суд признал не соответствующей Конституции ч. 10 ст. 127 Семейного кодекса Российской Федерации в части бессрочного запрета на усыновление детей для всех лиц, когда-либо признанных совершившими преступления, а также освобождавшихся от уголовной ответственности по нереабилитирующим основаниям, и указал законодателю на необходимость предоставить суду право решать вопрос о том, достойны ли такие лица (за исключением лиц, совершивших тяжкие и особо тяжкие преступления, а также преступления против половой неприкосновенности и половой свободы личности независимо от степени тяжести) усыновить ребенка с учетом всех сложившихся обстоятельств на момент рассмотрения вопроса об усыновлении в целях максимальной защиты прав и законных интересов усыновляемого, обеспечения его полноценного физического, психического, духовного и нравственного развития без риска быть подвергнутым какой-либо опасности ${ }^{13}$. Необходимые изменения в ст. 127 Семейного кодекса были внесены ${ }^{14}$. Однако поскольку никто не обращался в Конституционный Суд с жалобой о неконституционности такого же ограничения при решении вопросов об опекунстве (попечительстве), ч. 1 ст. 146 СК РФ («Опекуны (попечители) детей») остается до настоящего времени в старой редакции, содержащей соответствующий безоговорочный запрет.

Анализ указанных и иных федеральных законов и правовых позиций Конституционного Суда Российской Федерации позволяет сделать вывод о несовершенстве и противоречивости целого ряда подходов российского законодателя к решению вопросов установления правоограничений для лиц, признан-

9 О внесении изменений в отдельные законодательные акты Российской Федерации: Федеральный закон от 31 декабря 2014 г. № 237-Ф3.

10 По делу о проверке конституционности подпункта «а» пункта $3^{2}$ статьи 4 Федерального закона «Об основных гарантиях избирательных прав и права на участие в референдуме граждан Российской Федерации», части первой статьи 10 и части шестой статьи 86 Уголовного кодекса Российской Федерации в связи с жалобами граждан Г. В. Егорова, А. Л. Казакова, И. Ю. Кравцова, А. В. Куприянова, А. С. Латыпова и В. Ю. Синькова: Постановление Конституционного Суда Российской Федерации от 10 октября 2013 г. № 20-П.

11 О внесении изменений в отдельные законодательные акты Российской Федерации: Федеральный закон от 21 февраля 2014 г. № 19-Ф3; О выборах депутатов Государственной Думы Федерального Собрания Российской Федерации: Федеральный закон от 22 февраля 2014 г. № 20-ФЗ.

12 О внесении изменений в отдельные законодательные акты Российской Федерации: Федеральный закон от 23 мая 2020 г. № 153-Ф3.

13 По делу о проверке конституционности абзаца десятого пункта 1 статьи 127 Семейного кодекса Российской Федерации в связи с жалобой гражданина С. А. Аникеева: Постановление Конституционного Суда Российской Федерации от 31 января 2014 г. № 1-П.

14 О внесении изменений в Семейный кодекс Российской Федерации: Федеральный закон от 20 апреля 2015 г. № $101-Ф 3$. 
ных совершившими преступления, и наметить пути их устранения.

1. Прежде всего следует констатировать, что содержание такой базовой меры уголовной ответственности, как судимость, недостаточно четко определено в уголовном законодательстве. Большинство ученых не усматривают в судимости какого-либо содержания, а воспринимают ее как правовую оболочку уголовной ответственности, которая содержит лишь угрозу возможного усиления наказания за вновь совершенное преступление (Музенник, 1998, с. 26), либо как состояние осужденности, осуждение, развернутое во времени, временную характеристику уголовной ответственности (Советское исправительно-трудовое право, 1989, с. 206). Даже те немногие, кто видит в судимости синоним уголовной ответственности (Тарбагаев, 1986, с. 62) или ее сущность (Кропачев, 2000, с. 51) либо одну из форм реализации уголовной ответственности (Тащилин, Годило, 2004, c. 54), относят возникающие для осужденного лица правоограничения не к содержанию, а к последствиям судимости. Неудивительно на этом фоне, что применительно к правоограничениям судимости законодатель в ст. 86 УК РФ также использует термин «правовые последствия». Попробуем разобраться в корректности такой постановки вопроса.

Независимо от различия во взглядах на ее сущность и содержание, судимость традиционно воспринимается как некое правовое состояние, порождаемое фактом осуждения лица за совершение преступления по вступившему в законную силу приговору суда. Эта позиция поддерживается не только большинством ученых, занимавшихся данной проблемой (Гришко, Потапов, 2009, с. 181-190), но и Конституционным Судом Российской Федерации, который, исходя из анализа ч. 1 ст. 86 УК РФ, констатирует: «Судимость, таким образом, представляет собой правовое состояние лица, обусловленное фактом осуждения и назначения ему по приговору суда наказания за совершенное престу- пление и влекущее при повторном совершении этим лицом преступления установленные уголовным законодательством правовые последствия...» ${ }^{15}$.

Парадокс сложившейся правовой ситуации применительно к институту судимости заключается в том, что, говоря о последствиях судимости, законодатель тем самым не проясняет вопрос о ее содержании. Очевидно, что оно не сводится только к факту осуждения, a, скорее, представляется состоянием осужденности на протяжении установленного в законе срока. Если бы судимость сводилась только к констатации в приговоре суда вины лица в совершении того или иного преступления, то было бы понятно, что все правоограничения, возлагаемые на него после вступления приговора в законную силу, действительно являются последствиями (уголовно-правовыми или общеправовыми) такого юридического факта. Однако если вести речь о том, что на лицо в период судимости возлагаются определенные правоограничения, которые после погашения или снятия судимости аннулируются, то логично называть такие ограничения прав и свобод осужденного не последствиями, а содержательными компонентами судимости. О по-

следствиях судимости тоже можно вести речь, но лишь в том случае, если какими-либо федеральными законами установлены ограничения правового статуса лица не только в период судимости, но и после ее погашения или снятия.

Двойственность восприятия содержания и последствий судимости возникла не случайно, она производна от уникальной правовой природы судимости. В сравнительно недалеком прошлом, в дореволюционный и советский периоды, отечественный законодатель стоял на совершенно иных позициях. Как в Уложении о наказаниях уголовных и исправительных 1845 г. (Чистяков, 1988, с. 177-188), так и в Уголовном уложении 1903 г. (Чистяков, 1994, с. 278-283) имелось такое комплексное дополнительное наказание, как

15 По делу о проверке конституционности положений Уголовного кодекса Российской Федерации, регламентирующих правовые последствия судимости лица, неоднократности и рецидива преступлений, а также пунктов $1-8$ постановления Государственной Думы от 26 мая 2000 года «Об объявлении амнистии в связи с 55-летием Победы в Великой Отечественной войне 1941 - 1945 годов» в связи с запросом Останкинского межмуниципального (районного) суда города Москвы и жалобами ряда граждан: Постановление Конституционного Суда Российской Федерации от 19 марта 2003 г. № 3-П. 
лишение и ограничение прав, которое включало лишение прав сословия (состояния), поражение служебных прав и преимуществ, поражение прав семейных и собственности (имущественных). После Октябрьской революции 1917 г. указанный законодательный подход сохранялся в Уголовном кодексе РСФСР 1922 г. и в его редакции 1926 г. В соответствии со ст. 31 УК РСФСР эта мера заключалась в лишении на срок не свыше 5 лет активного и пассивного избирательного права, права занимать ответственные государственные должности, исполнять общественные обязанности и носить почетное звание, права занятия выборных должностей в промышленных и торговых организациях и обществах, родительских прав. Эти поражения в правах могли назначаться в совокупности или по отдельным их категориям (Сборник материалов по истории социалистического уголовного законодательства (19171937 гг.), 1938, с. 232-234).

Однако уже в Уголовный кодекс РСФСР 1960 г. названное наказание включено не было, поскольку российский законодатель пошел по весьма необычному пути закрепления большинства указанных и иных правоограничений в иных нормативных актах законного и подзаконного характера, относя их к правопораженному статусу лиц, являющихся судимыми. Такой подход, конечно, существенно затруднил как на практическом, так и на теоретическом уровне идентификацию данных правоограничений как уголовно-правовых. В результате поражения права, когда-то заключенные в комплексном дополнительном наказании, в большинстве своем приобрели статус правоограничений, обязательных для всех лиц, привлеченных к уголовной ответственности. На настоящий момент лишь незначительная часть таких правоограничений сохранилась в статусе наказаний: лишение права занимать определенные должности или заниматься определенной деятельностью (ст. 47 УК РФ) и лишение специального, воинского или почетного звания, классного чина и государственных наград (ст. 48 УК РФ).

Поскольку столь резкая смена статуса правоограничений, сравнительно недавно входивших в содержание указанного дополнительного наказания, теорией уголовного права до конца еще не осознана, мы имеем весьма противоречивый институт судимости, содержательная часть которого распределена во множестве федеральных законов, непосредственно не направленных на борьбу с преступностью (Нечепуренко, 2019, с. 37-43).

В странах дальнего зарубежья такой подход воспринят не был, и там поражение прав сохраняется в качестве дополнительного наказания. При этом дискуссии о том, могут ли в содержание данного наказания входить различные общеправовые ограничения, не возникает. Этот факт констатируется в монографических работах российских ученых, посвященных сравнительному правоведению в уголовном праве (Малиновский, 2002, с. 196-205; Додонов, 2010, с. 329-339). Наиболее показательна в этом контексте французская система лишения прав. Например, В. Н. Додонов отмечает, что в уголовном законодательстве большинства романоязычных стран, воспринявших эту систему, выделяются следующие виды специального поражения в правах:

1) лишение активного и пассивного избирательного права;

2) лишение публичной должности или права занятия ее;

3) лишение права заниматься определенной профессией или ремеслом;

4) лишение права свидетельствовать в суде, за исключением дачи обычных объяснений;

5) лишение права быть опекуном или попечителем;

6) лишение прав управлять транспортным средством;

7) запрещение хранения или ношения оружия и др. (Додонов, 2010, с. 331-332).

Как видим, общеправовой характер указанных правоограничений не мешает законодателю относить их к содержанию такого уголовного наказания, как лишение прав.

В связи с этим российскому законодателю, не меняя сложившегося статуса судимости, было бы полезно определиться с объемом как уголовно-правовых и уголовно-исполнительных, так и иных правоограничений, которые следует относить к содержанию судимости и которые должны аннулироваться в обязательном порядке после погашения или снятия судимости, т. е. с момента окончания уголовной ответственности. Исчерпывающий перечень таких правоограничений судимости есть смысл указать в следующем УК РФ. Объем этих правоограничений, изменяющийся в сторону уве- 
личения в зависимости от нарастания тяжести совершенного лицом преступления, как раз и составлял бы содержание судимости. При наличии перечня невозможно было бы устанавливать новые правоограничения в отношении судимого лица, не внеся соответствующих изменений в данную статью Уголовного кодекса Российской Федерации. Кроме того, само существование такого перечня оказывало бы весьма существенное превентивное воздействие на лиц, склонных к совершению преступлений.

Итак, следует обратить внимание на тот факт, что совершенно незаслуженно судимость занимает положение некой правовой структуры, подчиненной наказанию и без него самостоятельного значения не имеющей. Эта позиция, до сих пор поддерживаемая широкой научной общественностью, настолько прочно укоренилась в сознании законодателя, что, согласно ч. 2 ст. 86 УК РФ лица, освобожденные от наказания, считаются несудимыми, хотя данное положение противоречит смыслу ст. 73, 79, 81, 82, $82^{1}$ УК РФ. На самом деле судимость является атрибутом уголовной ответственности, ее базовой формой реализации, и ее основанием служит не наказание, а совершение преступления. В связи с этим срок погашения и снятия судимости следует исчислять не с момента отбытия наказания, а с момента вступления обвинительного приговора в законную силу, как это и указано в ч. 1 ст. 86 УК РФ. В пределах срока судимости за преступление той или иной категории и должны реализовываться такие формы уголовной ответственности, как наказание и испытание. Для этого следует установить определенные сроки судимости за преступление каждой категории. Они должны быть достаточно большими, чтобы вместить в себя все возможные варианты назначения наказания по совокупности преступлений и совокупности приговоров применительно к срочному лишению свободы. Например, за преступления небольшой тяжести - 5 лет, средней тяжести - 10 лет, тяжкие - 20 лет, особо тяжкие - 40 лет. Такие большие сроки судимости, конечно, должны предполагать возможность их погашения судом по истечении половины срока (подробнее: Нечепуренко, 2014, с. 92-112, 140-141). Только при пожизненном лишении свободы срок судимости должен быть также пожизненным, независимо от помилования осужденного или его условно-досрочного освобождения. Предполагается, что при таких больших сроках судимости сама собой отпадет необходимость устанавливать какие-либо еще сроки после ее погашения или снятия для ограничения лиц, совершивших преступления, в определенных правах, в том числе и в пассивном избирательном праве, как это совершенно произвольно установлено в настоящее время российским законодателем во исполнение упомянутого выше постановления Конституционного Суда Российской Федерации. При этом в Уголовном кодексе следует указать, что окончательное наказание по совокупности преступлений и совокупности приговоров не может быть больше срока судимости за наиболее тяжкое из совершенных преступлений.

2. Вопрос о законодательном регулировании института освобождения от уголовной ответственности является одним из наиболее сложных и спорных в теории уголовного права. Нормы об освобождении от уголовной ответственности были введены в УК РСФСР 1960 г. в рамках института назначения наказания и освобождения от него и первоначально предусматривали такое освобождение по пяти нереабилитирующим основаниям: давность привлечения к уголовной ответственности (ст. 48), изменение обстановки (ч. 1 ст. 50), передача дела в товарищеский суд (ст. 51), передача на поруки (ст. 52), передача материалов дела на рассмотрение комиссии по делам несовершеннолетних (ст. 10). Указом Президиума Верховного Совета РСФСР от 11 марта 1977 г. УК РСФСР пополнился еще одной разновидностью освобождения от уголовной ответственности - с привлечением к административной ответственности (ст. 50²). Указанные нормы об освобождении от уголовной ответственности достаточно широко применялись вплоть до начала 1990-х гг. Так, в 1990 г. 40 \% всех выявленных лиц, совершивших преступления, не были осуждены по приговорам суда, вступившим в законную силу. Абсолютное большинство таких лиц было освобождено от уголовной ответственности по различным нереабилитирующим основаниям ${ }^{16}$.

В тот период наметились две разнонаправленные тенденции относительно закрепления данного института в будущем уголовном законодательстве. Группой ведущих советских ученых отстаивалась точка зрения, что, несмотря на некоторое противоречие ст. 160 Конституции СССР, недостатки данного уголовно-правового института преодолимы и он имеет право на существование. Основным недостатком называлось чрезмерно широкое усмотрение правоприменительных органов при применении отдельных видов освобождения от уголовной ответственности. В связи с этим предполагалось, что институт освобождения от уголовной ответственности должен остаться в будущем российском уголовном законодательстве, но претерпеть существенные изменения.

На этом фоне противоположную позицию по отношению к институту освобождения от уголовной ответственности занял в тот период Комитет конституционного надзора СССР. В 1990 г. этим высшим судебным органом нормы уголовного и уголовно-процессуального законодательства, позволяющие признавать лицо

\footnotetext{
16 Преступность и правонарушения (1990 - 1994): статистический сборник. - М., 1995. С. 19.
} 
виновным в совершении преступления и освобождать его от уголовной ответственности, были признаны противоречащими Конституции СССР. Указанное противоречие законодателю предлагалось устранить в процессе обновления соответствующего законодательства ${ }^{17}$. Данное заключение было вынесено в связи с рассмотрением вопроса о конституционности такого широко применяемого основания освобождения от уголовной ответственности, как изменение обстановки (Филимонов В. Д., 2008, 238-239). Верховный Совет СССР проигнорировал это указание и в принятых 2 июля 1991 г., но так и не вступивших в силу Основах уголовного законодательства Союза ССР и республик сохранил возможность освобождения от уголовной ответственности лиц, совершивших преступления, по основаниям и в порядке, предусмотренным уголовными кодексами республик, указав, однако, что такое освобождение должно производиться судом и не допускаться, если лицо, совершившее преступление, против этого возражает (ст. 48 Основ) ${ }^{18}$.

В последующих законопроектных работах, касающихся уголовного законодательства Российской Федерации, курс на сохранение института освобождения от уголовной ответственности в целом был подтвержден, и, как результат, в УК РФ 1996 г. появилась глава 11, в которой первоначально предусматривалось, что все указанные в ней виды освобождения от уголовной ответственности будут носить безусловный характер и применяться только в случае совершения преступления небольшой тяжести. Этот порядок сохранялся семь лет, а в последующем наблюдались как расширение сферы применения имеющихся оснований освобождения от уголовной ответственности, так и закрепление в законе новых оснований. Наконец, Федеральным законом от 3 июля 2016 г. № 323-Ф3 был введен условный вид освобождения от уголовной ответственности с назначением судебного штрафа, вызвавший, пожалуй, наиболее оживленную научную дискуссию по поводу своей обоснованности и целесообразности (Звечаровский, 2016; Кудрявцев, Сутягин, 2016; Соктоев, 2017; Мартыненко, Мартыненко, 2017).

Зададимся вопросом, возможно ли попытаться изменить сложившуюся ситуацию с массовым применением института освобождения от уголовной ответственности?
Очевидно, что решающее значение в вопросе сохранения и развития данного института в российском уголовном законодательстве играет экономичность для системы уголовной юстиции за счет масштабности и стабильности его применения. Наиболее массовый характер носит освобождение от уголовной ответственности по такому основанию, как примирение с потерпевшим (ст. 76 УК РФ). Только на судебной стадии в 2013 г. по одному этому основанию было прекращено 185071 уголовное дело. По-прежнему оставаясь самым массовым из всех оснований освобождения от уголовной ответственности, данная практика в последние годы существенно снижалась, составив в 2020 г. 99117 уголовных дел. Происходило это главным образом за счет введения и активного применения судами освобождения от уголовной ответственности с назначением судебного штрафа. Если в 2017 г. по ст. $76^{2}$ УК РФ было прекращено 20692 уголовных дела, то в 2020 г. - уже 56 980. Всего по нереабилитирующим основаниям, указанным в главе 11 УК РФ, в 2020 г. судом были прекращены уголовные дела в отношении 175594 человек ${ }^{19}$. Как видим, судебная практика освобождения от уголовной ответственности по нереабилитирующим основаниям на протяжении ряда лет остается стабильно высокой, меняются только приоритеты правоприменителя в отношении того или иного вида освобождения. Если даже не принимать во внимание достаточно обширную практику освобождения от уголовной ответственности на досудебной стадии, сведения о которой отсутствуют в открытом доступе, то и в этом случае можно представить, как многократно увеличился бы весь комплекс затрат на функционирование системы уголовной юстиции в случае ликвидации как всего института освобождения от уголовной ответственности, так и его отдельных наиболее широко применяемых норм.

При всей неоднозначности института освобождения от уголовной ответственности с конституционной точки зрения очевидно, что он очень важен как один из маркеров, используемых законодателем при установлении определенных ограничений для лиц, совершивших преступления. Предусмотренный в ряде федеральных законов пожизненный запрет поступления на правоохранительную службу и на ее прохождение лиц, не только имеющих или имевших судимость, но и осво-

17 О несоответствии норм уголовного и уголовно-процессуального законодательства, определяющих основания и порядок освобождения от уголовной ответственности с применением мер административного взыскания или общественного воздействия, Конституции СССР и международным актам о правах человека: заключение Комитета конституционного надзора СССР от 13 сентября 1990 г. № 2-8 // Ведомости Съезда народных депутатов СССР и Верховного Совета СССР. 1990. № 39. Ст. 775.

18 Известия. 1991. 20 июля.

19 Данные рассчитаны по: Сводные статистические сведения о состоянии судимости в России. Ф. 10.2 «Отчет об особенностях рассмотрения уголовных дел, применения реальных видов наказания и основаниях прекращения уголовных дел» [Электронный ресурс]. Судебный департамент при Верховном Суде Российской Федерации // http: //www.cdep.ru. 
бождавшихся от уголовной ответственности по нереабилитирующим основаниям, призван закрыть для лиц, продемонстрировавших совершением преступления пренебрежение к установленным нормам поведения в обществе, наиболее значимые для государства сферы деятельности, связанные с высокими репутационными требованиями. Другое дело, что в таком случае данный запрет должен быть сформулирован универсально во всех соответствующих законах, регламентирующих правоохранительную деятельность. В настоящее время этого не наблюдается. Так, анализ указанных ранее федеральных законов показывает, что данный запрет в большинстве из них сформулирован путем перечисления лишь части оснований освобождения от уголовной ответственности. При этом не называется два таких основания, как освобождение от уголовной ответственности в связи с возмещением ущерба (ст. $76^{1}$ УК РФ) и в связи с назначением судебного штрафа (ст. $76^{2}$ УК РФ), хотя первое из оснований было введено в УК РФ еще в 2011 г., а второе в 2016 г. По букве закона отказать в приеме на службу в такие правоохранительные структуры, как органы внутренних дел, органы принудительного исполнения, уголовно-исполнительная система, Следственный комитет, Федеральная служба безопасности, лицам, освобожденным от уголовной ответственности по двум этим основаниям, нельзя.

В плане универсализации данного запрета следует отметить формулировку, не позволяющую претендовать на должность судьи. В пункте 2 ст. 4 указанного выше Закона РФ «О статусе судей в Российской Федерации» сказано, что судьей может быть «гражданин, не имеющий или не имевший судимости либо уголовное преследование в отношении которого прекращено по реабилитирующим основаниям». Тем самым от обратного указано, что не может быть судьей гражданин, освобожденный от уголовной ответственности по любому из нереабилитирующих оснований. Сходную универсальную формулировку относительно освобождения по нереабилитирующим основаниям следует в ближайшее время ввести во все федеральные законы, где она изложена с подобными пробелами.

Более того, необходимо на самом высоком уровне рассмотреть вопрос о единстве требований к кандидатам на поступление в любые государственные правоохранительные органы. Например, сейчас для сотрудников таможни законодательно закреплено требование всего лишь не иметь непогашенной или неснятой судимости. Как ни парадоксально, но и для кандидатов в прокуроры достаточно того, что они не имеют или не имели судимости. О запрете занимать такую должность лицам, ранее освободившимся от уголовной ответственности по нереабилитирующим основаниям, в Федеральном законе «О прокуратуре Российской Федерации» ничего не говорится.

\section{7}

3. Обратим внимание еще на ряд принципиальных моментов, касающихся законодательного установления пределов правоограничений для лиц, совершивших преступления:

3.1. Согласно ч. 2 ст. 86 УК РФ лица, освобожденные от уголовного наказания, считаются несудимыми. Речь в данном случае идет о лицах, освобожденных от наказания в связи с изменением обстановки (ст. $80^{1}$ УК РФ), по болезни (ч. 1 ст. 81), в связи с истечением сроков давности обвинительного приговора суда (ст. 83), несовершеннолетнего (ст. 92) и по амнистии (ст. 84). На них в настоящее время не распространяются многочисленные общеправовые правоограничения, хотя фактически они также являются лицами, совершившими преступления, причем в ряде случаев представляют большую общественную опасность, чем освобожденные от уголовной ответственности по нереабилитирующим основаниям. Исключение составляет Федеральный закон «О государственной охране», где с 1 июля 2017 г. в новой редакции подп. 4 п. 5 ст. 18 наряду с судимостью и освобождением от уголовной ответственности по некоторым нереабилитирующим основаниям закреплено и освобождение от уголовного наказания в качестве запрета поступления на такую службу ${ }^{20}$. Следует восполнить данный пробел, указав во всех федеральных законах, регулирующих службу в правоохранительных органах, что освобождение от уголовного наказания, не влекущее судимость, также

20 О внесении изменений в Федеральный закон «О государственной службе» и отдельные законодательные акты Российской Федерации : Федеральный закон от 1 июля 2017 г. № 148-ФЗ. 
является основанием для запрета поступать на такую службу или находиться на ней.

3.2. Следует отказаться от более мягкого подхода к судимым, занимающим должности муниципальной службы, по сравнению с государственными гражданскими служащими, поскольку и те и другие относятся к представителям публичной власти. Логично внести соответствующие изменения в Федеральный закон «О муниципальной службе в Российской Федерации» и на муниципальную службу не принимать лиц, имеющих судимость за любое преступление, а не только «осужденных к наказанию, исключающему возможность исполнения должностных обязанностей по муниципальной службе», как это закреплено в настоящее время ${ }^{21}$.

3.3. Требуется внести изменения и в ст. 146 Семейного кодекса Российской Федерации, которые определяли бы для лиц, совершивших преступления, те же возможности добиваться через суд установления опеки (попечительства) над детьми, как это предусмотрено в ст. 127 СК РФ применительно к усыновителям в соответствии с указанной выше правовой позицией Конституционного Суда Российской Федерации.

\section{Закиючение}

Анализ правовых позиций Конституционного Суда Российской Федерации позволяет понять, что в вопросе законодательного регулирования ограничений прав и свобод лиц, совершивших преступления, сложилась далеко небезупречная ситуация. С одной стороны, законодатель по известным только ему соображениям вводит пожизненные правоограничения для таких лиц, а спустя несколько лет выясняется, что эти правоограничения чрезмерны с точки зрения реализации указанными лицами своих конституционных прав избираться в представительные органы власти страны или выбирать род трудовой деятельности в соответствии со своей квалификацией и предпочтениями. С другой стороны, устанавливаемые во множестве федеральных законов запреты на осуществление той или иной трудовой деятельности для лиц, совершивших преступления, нуждаются в ревизии, поскольку изначально законодатель не установил определенные универсальные критерии обоснованности введения подобных запретов. Особенно запутанной и противоречивой выглядит ситуация с запретами на службу в правоохранительных органах, где к кандидатам и к действующим сотрудникам предъявляются максимально высокие репутационные требования. Очевидно, что отказ от выделения в 2015 г. правоохранительной службы в структуре государственной службы отрицательно сказался на законодательном регулировании деятельности отдельных ее структур, в том числе и в вопросах комплектования кадров. Отсюда и тавтологичные, избыточные, юридически непродуманные формулировки, касающиеся запретов на такую службу для лиц, имеющих или имевших судимость или освобождавшихся от уголовной ответственности по нереабилитирующим основаниям. Решать накопившиеся проблемы с закреплением в федеральных законах правоограничений для лиц, совершивших преступления, необходимо с учетом переосмысления сущности и содержания уголовно-правовых институтов судимости и освобождения от уголовной ответственности, поскольку, используя, прежде всего, их, законодатель способен сформулировать взвешенные конституционно обоснованные положения, касающиеся данной сферы социального бытия.

\section{Список митературы}

Гришко, А. Я., Потапов, А. М. (2009). Амнистия. Помилование. Судимость. Москва: Логос.

Додонов, В. Н. (2010). Сравнительное уголовное право: монография, общая часть. Москва: Юрлитинформ.

Звечаровский, И. Э. (2016). О юридической природе судебного штрафа. Уголовное право, 6, 98-101.

Кропачев, Н. М. (2000). Механизм уголовно-правового регулирования: дис. ... д-ра юрид. наук в форме научного доклада. Санкт-Петербург.

Кудрявцева, А. В., Сутягин, К. И. (2016). Судебный штраф. Уголовное право, 6, 102-110.

Малиновский, А. А. (2002). Сравнительное правоведение в сфере уголовного права. Москва: Международные отношения.

Мартыненко, Н. Э., Мартыненко, Э. В. (2017). Судебный штраф как иная мера уголовно-правового характера. Трудь Академии управления МВД России, 1, 24-27.

Марцев, А. И. (2012). Преступление: социально-правовой анализ. Омск: Омская академия МВД России.

Музеник, А. К. (1998). Дифференциация уголовной ответственности: формы и виды. Уголовное право и современность: межвуз. сб. науч. тр. (Стр. 21-26). Красноярск.

Нечепуренко, А. А. (2019). Разграничение содержания и последствий судимости. Научный вестник Омской академии МВД России, 4, 3-8.

Нечепуренко, А. А. (2014). Уголовная ответственность: эволюичя понятия и перспективы законодательного регулирования. Омск: Омская академия МВД России.

Никифоров, Б. С. (1981). Наказание и его цели. Советское государство и право, 9, 63-71.

Чистяков, О. И. (ред.) (1988). Законодательство первой половины XIX в. В Российское законодательство $X-X X$ веков (Т. 6). Москва: Юридическая литература.

Чистяков, О. И. (ред.) (1994). Законодательство эпохи буржуазно-демократических революций. В Российское законодательство X-XX веков (Т. 9). Москва: Юридическая литература.

\footnotetext{
21 О муниципальной службе в Российской Федерации : Федеральный закон от 2 марта 2007 г. № 25-Ф3 (ст. 3).
} 
Сборник материалов по истории социалистического уголовного законодательства (1917-1937 гг.) (1938). Москва: Юрид. изд-во НКЮ СССР.

Советское исправительно-трудовое право (1989). Ленинград.

Соктоев, 3. (2017). Проблемы применения норм о судебном штрафе. Уголовное право, 1, 90-94.

Тарбагаев, А. Н. (1986). Понятие и цели уголовной ответственности. Красноярск: Изд-во Краснояр. ун-та.

Тащилин, М., Годило, Н. (2004). Уголовная ответственность и формы ее реализации. Уголовное право, 4, 53-54.

Кудрявцев, В. Н., Келина, С. Г. (ред.) (1987). Уголовный закон. Опыт теоретического моделирования. Москва: Наука.

Филимонов, В. Д. (1970). Общественная опасность личности преступника. Томск: Изд-во Том. ун-та.

Филимонов, В. Д. (2008). Уголовная ответственность по российскому законодательству. Москва: ЮрИнфоР-МГУ.

\section{References}

Grishko, A. YA., Potapov, A. M. (2009). Amnistiya. Pomilovanie. Sudimost'. Moskow: Logos.

Dodonov, V. N. (2010). Sravnitel'noe ugolovnoe pravo: monografiya, obshchaya chast'. Moskow: YUrlitinform.

Zvecharovskij, I. E. (2016). O yuridicheskoj prirode sudebnogo shtrafa. Ugolovnoe pravo, 6, 98-101.

Kropachev, N. M. (2000). Mekhanizm ugolovno-pravovogo regulirovaniya: dis. ... d-ra yurid. nauk v forme nauchnogo doklada. Saint Petersburg.

Kudryavceva, A. V., Sutyagin, K. I. (2016). Sudebnyj shtraf. Ugolovnoe pravo, 6, 102-110.

Malinovskij, A. A. (2002). Sravnitel'noe pravovedenie v sfere ugo-lovnogo prava. Moskow: Mezhdunarodnye otnosheniya.

Martynenko, N. E., Martynenko, E. V. (2017). Sudebnyj shtraf kak inaya mera ugolovno-pravovogo haraktera. Trudy Akademii upravleniya MVD Rossii, 1, 24-27.

Marcev, A. I. (2012). Prestuplenie: social'no-pravovoj analiz. Omsk: Omskaya akademiya MVD Rossii.

Muzenik, A. K. (1998). Differenciaciya ugolovnoj otvetstvennosti: formy i vidy. Ugolovnoe pravo i sovremennost': mezhvuz. sb. nauch. tr. (Str. 21-26). Krasnoyarsk.

Nechepurenko, A. A. (2019). Razgranichenie soderzhaniya i posledstvij sudimosti. Nauchnyj vestnik Omskoj akademii MVD Rossii, 4, 3-8.

Nechepurenko, A. A. (2014). Ugolovnaya otvetstvennost': evolyuciya po-nyatiya i perspektivy zakonodatel'nogo regulirovaniya. Omsk: Omskaya akademiya MVD Rossii.

Nikiforov, B. S. (1981). Nakazanie i ego celi. Sovetskoe gosudarstvo i pravo, 9, 63-71.

Chistyakov, O. I. (red.) (1988). Zakonodatel'stvo pervoj poloviny XIX v. V Rossijskoe zakonodatel'stvo X-XX vekov (T. 6). Moskow: YUridicheskaya literatura.

Chistyakov, O. I. (red.) (1994). Zakonodatel'stvo epohi burzhuazno-demokraticheskih revolyucij. V Rossijskoe zakonodatel'stvo $X-X X$ vekov (T. 9). Moskow: YUridicheskaya literatura.

Sbornik materialov po istorii socialisticheskogo ugolovnogo zakonodatel'stva (1917-1937 gg.) (1938). Moskow: YUrid. izd-vo NKYU SSSR.

Sovetskoe ispravitel'no-trudovoe pravo (1989). Leningrad.

Soktoev, Z. (2017). Problemy primeneniya norm o sudebnom shtrafe. Ugolovnoe pravo, 1, 90-94.

Tarbagaev, A. N. (1986). Ponyatie i celi ugolovnoj otvetstvennosti. Krasnoyarsk: Izd-vo Krasnoyar. un-ta.

Tashchilin, M., Godilo, N. (2004). Ugolovnaya otvetstvennost' i formy ee realizacii. Ugolovnoe pravo, 4, 53-54.

Kudryavcev, V. N., Kelina, S. G. (red.) (1987). Ugolovnyj zakon. Opyt teoreticheskogo modelirovaniya. Moskow: Nauka.

Filimonov, V. D. (1970). Obshchestvennaya opasnost' lichnosti prestupnika. Tomsk: Izd-vo Tom. un-ta.

Filimonov, V. D. (2008). Ugolovnaya otvetstvennost' po rossijskomu zakonodatel'stvu. Moskow: YUrInfoR-MGU.

\section{Информация об авторе:}

Нечепуренко Алексей Алексеевич - начальник редакционно-издательского отдела Омской академии МВД России, доктор юридических наук, профессор.

\section{About the author:}

Alexey A. Nechepurenko - Chief of The Editorial Staff of the Omsk Academy of the Ministry of Internal Affairs of Russia, Doctor of Law, Professor.

Статья поступима в реАакцию 15.08.2021; одобрена после рецензирования 01.10.2021; принята к публикации 29.10.2021.

The article was submitted August 15, 2021; approved after reviewing October 01.2021; accepted for publication October 29, 2021.

Автор заявляет об отсутствии конфликта интересов.

The author declare no conflicts of interests. 